\title{
COGNITIVE ASPECT OF LEARNING STYLE IN DIFFERENTIATED ESP INSTRUCTION FOR THE FUTURE IT SPECIALISTS
}

\author{
Oksana Synekop \\ National Technical University of Ukraine "Igor Sikorsky Kyiv Polytechnic Institute”, \\ Kyiv, Ukraine \\ oksana.synekop@gmail.com
}

\begin{abstract}
The paper deals with the issue of cognitive aspect of learning style of information technology (IT) students that is urgent in organising differentiated instruction of English for Specific Purposes at universities. R. Oxford's Style Analysis Survey and R. Amthauer's testing of intelligence have been used for studying the cognitive aspect. As the specifics of IT field are focused on such actions of IT specialists as perception, processing and implementation of textual, symbolic, graphical information, presented in oral and written forms, the most valuable parameters for organising the learning process and work with information for the future IT specialist are sensory modality (auditory, visual and kinesthetic) and the way of processing information (analytic and synthetic). Testing the third-year IT students and the fourth-year IT students has confirmed the statement of R. Oxford that learning styles are not dichotomous. Also, testing has shown that among auditory, visual, kinesthetic and mixed modalities of IT students, the dominant sensory modalities are auditory and mixed. Mixed modalities are represented by four groups of students: learners with visual, auditory and kinesthetic modality; learners with visual and kinesthetic modality; learners with visual and auditory modality; learners with auditory and kinesthetic modality. Testing results of the third-year and the fourth-year IT students' way of processing ideas in the learning process indicate the tendency of predominance of the synthetic way of processing information and also mixed synthetic and analytic ways of processing information in the IT students. According to the R. Amthauer's test of the verbal and nonverbal intelligence of IT students can be presented as the relation 3 (spatial) $<1$ (mathematical) $<2$ (verbal). The theoretical and practical thinking of the third- and fourth-year IT students are relatively balanced. All the specifics of IT students should be taken into account in the differentiated instruction of English for specific purposes. The ways of using such specifics are presented in recommendations. Keywords: differentiated instruction; learning style; cognitive aspect; English for specific purposes; IT students.
\end{abstract}

\section{Introduction}

The tendency of intensive growth of the information technology(IT)-industry is dominant both in the whole world and in Ukraine in particular. Due to the successful development and implementation of highquality IT products by Ukrainian IT specialists, Ukraine is becoming an important participator of various international projects. This leads to the necessity of preparation of the intellectual potential of highly skilled and competitive IT specialists for the IT industry in higher educational institutions. Besides the knowledge and skills in the IT field, they have to master foreign language skills with the aim of successful communication for solving various professional issues. Therefore, there is a need to research the ways to improve the learning process of foreign language for specific purposes. One of the most efficient of them is the introduction of differentiated instruction. "The overarching goal of differentiated instruction is for teachers to maximise the potential of all learners by proactively designing learning experiences in response to individual needs" (Santangelo \& Tomlinson, 2012, p. 310). The scientists think that "learning is promoted when different learners are provided with different avenues of learning, according to their need" (Margaryan, Bianca, \& Littlejohn, 2015, p. 79). It implies that "teachers should focus their attention on three important student characteristics: readiness, interest, and learning profile" (Santangelo, Tomlinson, 2012, p. 312). Also "actual differentiated instruction implementation of teachers is linked to a complex set of variables as teachers' self-efficacy, teaching beliefs, teaching experience, professional development, teacher certification, and classroom size" (Suprayogi, Valcke, \& Godwin, 2017, p. 291), "a model of differentiation that should reflect the interdependence between environment, curriculum, assessment, and instruction" (Santangelo \& Tomlinson, 2012, p. 324).

For satisfying the needs of IT student in mastering foreign language various learning individual approaches, methods, techniques outlining a certain language learning style can be used. In the studies of educators and psychologists, the language learning style is perceived as "one of the factors that helps determine how - and how well - our students learn foreign language" (Oxford, 2003, p. 1) and determined as a specific of the actions used for achieving the purpose (Kondrashihina, 2009). At the same time, researchers use the notion "cognitive style", which they define as the individual's preferred and habitual modes of perceiving, remembering, organising, processing, and representing information (Dörnyei, 2005, p. 124). It is generally agreed, that the learning style is a multidimensional phenomenon (Oxford, 2003, p. 1) and is apparently overlapping a cognitive nature (Dörnyei 2005, p.160). In addition, the cognitive style is an integral part of the learning style (Grossman, 2011, p. 10). Thus, it creates the effect of immersing a 
cognitive style into language learning style. That is why in our research the cognitive style is considered as a separate aspect of the language learning style.

The analysis of the scientific literature shows that cognitive parameters are wide and include the following dimensions: independent/dependent, analytic/synthetic, reflective/impulsive and others. The cognitive aspect as a component of the learning style has been regarded by Grasha, 1984 (independent / dependent); Myers \& McCaulley, 1985 (sensing / intuitive, thinking / feeling, judging/ perceiving); Guild, 2001 (sensing / intuition, field dependence / field independence, abstract / concrete, visual, auditory, kinesthetic, tactile). Within the context of teaching English for specific purposes (ESP) to technical students at university Bondar (2011) highlights the cognitive aspect in language learning style.

Also, a connection of the cognitive aspect with the specifics of the professional activity of the IT specialists has been identified. For example, Bishop-Clark (1995) proves, that the cognitive styles and personality traits have the biggest impact on each of the four stages of programming (problem representation, design, coding, debugging) (p. 257). According to a study done by Mahadevan, Meservy, \& Simon (2011), the developer's cognitive style significantly impacts the information security policy compliance. This implies that different individual's strengths can influence the effectiveness of the work of IT specialists.

Teaching English to IT students in higher educational institutions is based on the content of professional disciplines, which allows creating the virtual professional environment through various communicative situations. Adapting teaching techniques to the cognitive features of IT students can satisfy most of their needs and permit the learners to "develop their professional language competences, enabling them to function effectively in culturally diverse academic and professional environments" (English for Specific Purposes. National Curriculum for Universities, 2005).

Among a wide range of requirements to the future IT specialists, it is possible to outline the following ones: to be able to create software, design and support computer hardware, maintain the information, look for vulnerabilities and reduce the risks, develop and support web pages/sites on the Internet, protect the company system against unauthorised access, etc. Consequently, the specifics of IT field are focused on such actions of IT specialists as the perception, processing and implementation of textual, symbolic, graphical information, presented in oral and written forms.

In general, cognition "involves receiving, obtaining, taking possession of, and discerning information, ideas, and concepts" (Guild, 2001). As mentioned above, within the cognitive style the researchers define different dimensions such as field dependent/field independent, analytic/synthetic, abstract/concrete, etc. Nevertheless, the most valuable for the work with information for the future IT specialist are sensory modality (auditory, visual, kinesthetic) and the way of processing information (analytic and synthetic).

According to Oxford (2003), learning styles are not dichotomous; they generally operate on a continuum or on multiple, intersecting continua (Oxford, 2003, p. 3). This implies that a student may have one dominant style, for example, an analytic way of thinking, or he/she may have a flexible approach to solving certain problems balancing between analytic and synthetic way of thinking in the learning process. Thus, it is urgent to define the dominant and auxiliary language learning style (Bondar, 2011) of the future IT specialists. In its turn, the auxiliary style of the IT students seems to be in the background but needs to be developed and improved.

In the context of defining different modalities, researchers differentiate "modality strength" and "modality preference". Some scientists (Tarver \& Dawson, 1978; Dunn, 1984) neglect this and use these concepts interchangeably. Nevertheless, "a modality strength can be operationally defined as the ability to perform a task in one of the major modalities" (Barbe, Swassing, \& Milone, 1979). "A modality preference is a person's opinion regarding the modality through which $\mathrm{s} /$ he learns best. For some children and adults, modality strengths and preferences coincide; this is not always the case, however, even for those who are gifted (Barbe \& Milone, 1982)". We support the opinion of the scientists that differentiate the notions but in our research, we use the term "modality dominance" because it is more precise and means power or superiority over other modalities of a learner. Also such terms as "dominant learning style" and/or "preferred learning style" are used (Derkach, 2018; Dörnyei, 2005; Cassidy, 2004). Taking into account the information above, the notion "dominant learning style" is acceptable.

Riding \& Rayner (1988) emphasise the fact that the cognitive aspect also includes the type of intelligence. It is known that the ability to learn as the intellect itself influences the success of mastering a foreign language as well as ESP.

Thus, differentiated instruction for the future IT specialists should be based on the study of the cognitive aspect of language learning and specifics of IT field. Consequently, the aim of this paper is to define and analyse the specifics of cognitive aspect of language learning style in differentiated instruction of ESP to IT 
students at university level, to define the main tendencies and cover the ways of adapting the learning process to the individual cognitive needs.

\section{Methods}

During the 2017-2018 academic years the R. Oxford's Style Analysis Survey for defining the language learning style dominances of the future IT specialists was conducted. This survey presents an analytical review of language learning style and has a number of advantages: firstly, it is developed for the needs of foreign language learning process; secondly, it allows one fully analyse the student's individual characteristics in terms of his/her cognitive activity in the future professional sphere; thirdly, it enables a flexible assessment of IT students.

Also, the psychological test of the structure of intellect of R. Amthauer for diagnosing verbal and nonverbal intelligence of IT students was used. The most important advantage of this test is its complexity to cover different sides of person's intelligence.

\section{Participants}

IT students of the Institute of Physics and Technology; Faculty of Informatics and Computer Science of National Technical University of Ukraine "Igor Sikorsky Kyiv Polytechnic Institute" participated in the survey during 2017-2018. The total number of the third and fourth year IT students who took part in the R. Oxford's test is 447 , in the R. Amthauer's test -393 .

\section{Instruments}

The R. Oxford's Style Analysis Survey.

The questionnaire is taken from Learning Styles Workshop of M. Walline (1996).

For the purposes of our research needs, we use the first and the fifth tests of the R. Oxford's Style Analysis Survey. The first test is to define visual, auditory, kinesthetic and mixed modality learners. It contains 30 items. Each item of questionnaire is indicated by one of the responses: $0=$ Never, $1=$ Sometimes, 2 = Very often, $3=$ Always. It is necessary to add the scores from the 1 st to the 10 th position (visual modality), from the 11th to the 20th position (auditory modality), from the 21 st to the 30th position (kinesthetic modality). The highest score indicates the dominant modality. If the difference between the first or/and the second or/and the third indicators is no more than 2 points, it means that a student has got equally developed visual and/or auditory and/or kinesthetic modality (mixed modality). This test takes 15 minutes to complete.

The fifth test is to identify analytic and synthetic learners and mixed analytic-synthetic learners. It consists of 20 items. Each item of questionnaire is indicated by one of the responses: $0=$ Never, $1=$ Sometimes, 2 = Very often, 3 = Always. The scores from the 1 st to the 10 th position (synthetic way of processing information), from the 11th to the 20th position (analytic way of processing information) are added. The highest score indicates the dominant way of processing information. If the difference between the first and the second indicators is no more than 2 points, it implies that a student has got equally developed the synthetic-analytic way of processing information. The test takes 10 minutes to complete.

\section{The R. Amthauer's test of the verbal and nonverbal intelligence}

The questionnaire is taken from Differential Psychology (Kondrashihina, 2009).

For the purposes of our research needs we use the block of verbal subtests (subtests 1-4); the block of nonverbal subtests that contains the mathematical subtests (subtests 5 and 6) and spatial subtests (subtests 7 and 8); the block of theoretical thinking subtests (subtests 2 and 4) and practical thinking subtests (subtests 1 and 3). There are 136 tasks. The test takes 54 minutes. In the subtests $1-3,5-8$ each correct answer is estimated at 1 point. In the subtest 4 the score ranges from 0 to 2 points. The results can be presented in the form of relative values - the percentage of student's points to the maximum possible. It is necessary to do this due to the fact that different blocks of tasks have different maximum possible number of points. For verbal subtests, the maximum is 92 points, for mathematical and spatial subtests - 40 points each, for theoretical thinking subtests -52 points, for practical thinking subtests -40 points. Therefore, for example, the percentage of student's verbal intelligence can be received in the following way:

$$
R_{\text {verbalintelligence }}=\frac{\text { student's total scores of subtests } 1-4}{92} \times 100 \%
$$

In the same way, mathematical, spatial intelligence, practical and theoretical thinking are calculated. 


\section{Results}

Testing 238 third year IT students for determining the sensory modality dominance has shown that $23.9 \%$ of students have auditory modality, $10.9 \%$ of students - visual modality, and only $7.98 \%$ of students dominant kinesthetic modality. Among 209 fourth year IT students, $22 \%$ have dominant auditory modality, $10 \%$ - visual modality, $5.7 \%$ - kinesthetic modality. Most of the third year IT students $(57.1 \%)$ and the fourth year IT students (61.9\%) have mixed sensory modality. According to Tight (2007), mixed sensory modality is the ability to function in more than one modality (p. 35). Traditionally, in the scientific literature learners with three dominate modalities are called digital/auditory-digital or discrete. They are capable of perceiving information through logical comprehension, using numbers and signs, logical inferences. Among the third year IT students, $10.5 \%$ are with equally developed visual, auditory and kinesthetic modality, $13 \%$ - with visual and kinesthetic modality, $13.9 \%$ - with visual and auditory modality, $19.7 \%$ - with auditory and kinesthetic modality. Testing the fourth year IT students has demonstrated that $15 \%$ are the students with equally developed visual, auditory and kinesthetic modality, $15.8 \%$ - with visual and kinesthetic modality, $10.5 \%$ - with visual and auditory modality, $20.6 \%$ - with auditory and kinesthetic modality. Comparing the third and fourth year IT students has shown that the dominant sensory modalities are auditory and mixed (Table 1).

Table 1

Sensory modality testing results of IT students

\begin{tabular}{|c|c|c|c|c|c|c|c|}
\hline \multirow{2}{*}{$\begin{array}{c}\text { Number } \\
\text { of } \\
\text { students }\end{array}$} & \multirow{2}{*}{$\begin{array}{c}\text { Visual } \\
\text { Modality }\end{array}$} & \multirow{2}{*}{$\begin{array}{l}\text { Auditory } \\
\text { Modality }\end{array}$} & \multirow{2}{*}{$\begin{array}{l}\text { Kinesthetic } \\
\text { Modality }\end{array}$} & \multicolumn{4}{|c|}{ Mixed Sensory Modality } \\
\hline & & & & $\begin{array}{c}\text { Visual, } \\
\text { Auditory } \\
\text { and } \\
\text { Kinesthetic } \\
\text { Modality }\end{array}$ & $\begin{array}{c}\text { Visual and } \\
\text { Kinesthetic } \\
\text { Modality }\end{array}$ & $\begin{array}{c}\text { Visual } \\
\text { and } \\
\text { Auditory } \\
\text { Modality }\end{array}$ & $\begin{array}{c}\text { Auditory } \\
\text { and } \\
\text { Kinesthetic } \\
\text { Modality }\end{array}$ \\
\hline \multicolumn{8}{|c|}{ Third-year IT students } \\
\hline \multirow[t]{2}{*}{238} & \multirow[t]{2}{*}{$10.9 \%$} & \multirow[t]{2}{*}{$23.9 \%$} & \multirow[t]{2}{*}{$7.98 \%$} & $10.5 \%$ & $13 \%$ & $13.9 \%$ & $19.7 \%$ \\
\hline & & & & \multicolumn{4}{|c|}{$57,1 \%$} \\
\hline \multicolumn{8}{|c|}{ Fourth-year IT students } \\
\hline \multirow[t]{2}{*}{209} & \multirow[t]{2}{*}{$10 \%$} & \multirow[t]{2}{*}{$22 \%$} & \multirow[t]{2}{*}{$5.7 \%$} & $15 \%$ & $15.8 \%$ & $10.5 \%$ & $20.6 \%$ \\
\hline & & & & \multicolumn{4}{|c|}{$61.9 \%$} \\
\hline
\end{tabular}

Testing 238 third year IT students for defining the students' dominant way of processing information in the learning process has demonstrated that the students can be divided into those who have dominance in the synthetic way of processing information $-51.7 \%$, the analytic way of processing information $-11.3 \%$ or combine both ways of processing information $-36.97 \%$. Among 209 fourth year IT students, $51.2 \%$ are with dominant synthetic way of processing information, $17 \%$ - with analytic way of processing information, $31.6 \%$ - with mixed synthetic-analytic ways of processing information. The test results of the third year and the fourth year IT students have indicated the tendency of predominance of synthetic way of processing information and also the mixed synthetic-analytic ways of processing information. It is illustrated in Table 2.

Testing results of IT students according to the way of information processing

Table 2

\begin{tabular}{|c|c|c|c|}
\hline $\begin{array}{c}\text { Number of } \\
\text { students }\end{array}$ & $\begin{array}{c}\text { Students with synthetic } \\
\text { way of processing } \\
\text { information }\end{array}$ & $\begin{array}{c}\text { Students with analytic } \\
\text { way of processing } \\
\text { information }\end{array}$ & $\begin{array}{c}\text { Students with mixed synthetic- } \\
\text { analytic ways of processing } \\
\text { information }\end{array}$ \\
\hline \multicolumn{4}{|c|}{ The third-year IT students } \\
\hline 238 & $51.7 \%$ & $11.3 \%$ & $36.97 \%$ \\
\hline \multicolumn{4}{|c|}{ The fourth-year IT students } \\
\hline 209 & $51.2 \%$ & $17 \%$ & $31.6 \%$ \\
\hline
\end{tabular}

R. Amthauer's testing involved 202 third year IT students and 191 fourth year IT students. The results have shown that the verbal intelligence (1) is characteristic of $62.43 \%$ of the third year IT students, and the nonverbal intelligence is represented as a combination of mathematical intelligence (2) and spatial intelligence (3) (characteristic of $75.37 \%$ and $54.84 \%$ of students, respectively). From this follows the ratio $3<1<2$, which shows that the dominant is the mathematical intelligence, followed by verbal intelligence and 
spatial intelligence. The verbal intelligence (1) is specific to $62.9 \%$ of the fourth year IT students, the nonverbal intelligence of students is presented as mathematical intelligence (2) and spatial intelligence (3) (specific to $79.24 \%$ and $54.4 \%$ of students, respectively). Thus, the ratio is $3<1<2$.

Also, with the use of the R. Amthauer's test, the correlation between theoretical (subtest 2,4) and practical (subtest 1,3) thinking of IT students has been determined. In particular, the average theoretical thinking level of the third year IT students makes up 58.57\%, the average practical thinking level $-68.69 \%$. At the same time the average theoretical thinking level of the fourth year IT students is $59.89 \%$ and the average practical thinking level $-67.99 \%$. Therefore, the levels of theoretical and practical thinking of the third and fourth year IT students are relatively balanced.

\section{Discussion}

Several issues for the discussion have emerged in the process of our research. The first issue is connected with identifying reasons that explain the dominance of learners with auditory modality and mixed sensory modality. According to Barbe and Milone (1981;1982) and Barbe, Swassing, and Milone (1979; 1981) modality strength is not a fixed characteristic. They clarify that infants are more kinesthetic than older children, pre-school and early primary grade children have comparatively strong auditory abilities, and older children and adults rely on vision rather than on audition and kinesthesia (Barbe and Milone (1981; 1982) Barbe, Swassing, and Milone (1979; 1981)). Also, the scientists mention that "the modalities become more integrated with age. Whereas younger children focus on a single perceptual aspect of an event, older children and adults are more likely to consider an event in terms of several perceptual characteristics. As a person grows older, there is an increase in the ability to transfer information from one modality to another" (Barbe \& Milone, 1982, p. 3). The investigation of Brooks, Anderson, Roach, McGraw, \& McKendrick (2015) devoted to aging affects in auditory and visual interactions, has shown the auditory modality dominance in younger adults (22-23 years old) and equalising auditory and visual influence in older adults (60-74 years old). We have also to take into consideration the following facts: 1) young generation grows up in the age of increasing amount of information and the rapid computerisation that needs person's quick perceiving, processing, applying data; 2) the requirements to the IT specialists are not limited to work on the computer but requires the ability to work in a team, to communicate with clients, etc. This can explain the leading position of auditory modality and mixed sensory modality.

The second issue deals with the specifics of different modalities and the ways of using them in learning ESP.

Taking into account the information about auditory, visual and kinesthetic modality represented by the different researchers (Oxford, 1992, pp. 40-42; Oxford, 2003, pp. 3-4; Leaver, 2000; Tight, 2007), we are going to characterise the sensory modalities of IT students.

With a dominant visual modality the students "like to read and obtain a great deal from visual stimulation" (Oxford, 2001, p. 3-4) such as pictures, diagrams, flow charts, time lines, films (Felder, 1995, p. 23; Leaver, 2000, p. 68; Dörnyei, 2005, p. 140), prefer to complete written assignments, to provide written evaluation (Dreyer \& Van der Walt, 1996, p. 473), are able to image mental pictures (Tight, 2007, p. 33). Thus, IT students better perceive the text information in print/electronic format supported by tables, circuits, graphics, diagrams, mind maps using mostly visual memory. Reading and writing activities are dominant for visuals in foreign language communication on professional topics. In order to avoid difficulties during speaking, it is necessary to give them time to prepare the discussion or monologue, to use visual aids; to work initially alone, then in pairs, and after that to participate in small and whole class groups. When teaching listening, it is acceptable to variate the tempo, to offer students to use subtitles, to make notes during listening.

Auditory students are "comfortable without visual input and therefore enjoy and profit from unembellished lectures, conversations, and oral directions, ... are excited by classroom interactions in roleplays" (Oxford, 2003, p. 3-4), enjoy listening to others, have difficulty with written work (Oxford, 1996), like to "talk the material through" by engaging in discussions and group work (Dörnye, 2005, p. 140). Therefore, in the learning and future professional environment IT students better perceive information while listening and speaking, easily paraphrase, quickly adapt to audio/video texts of different length presented at different speeds; actively participate in brainstorming, discussions, interviews, debates on professional topics; prefer group work; role-plays; work in a team. At the same time, reading and writing will contribute to better information processing. In this regard, a teacher may offer IT students to interpret the information in the written form which they previously read or listened to.

Kinesthetic students "prefer lots of movement and enjoy working with tangible objects, collages, and flashcards" (Oxford, 2003, pp. 3-4); "enjoy making posters, collages, and other types of visuals, building 
models" (Dörnyei, 2005, p. 140). Thus, they work better in the learning environment focused on participation in discussions, role plays, and practical experimentation. Correspondingly, in the professional activity, they prefer direct participation in the general information process, in work with a computer. Such students can methodically explain what happens, describe information related to practical use, provide reasoning. Also, they need to involve visual and audio systems, for example, through recording information for oral or written reproduction.

As already mentioned, a student with mixed modality (visual, auditory, kinesthetic; visual, kinesthetic; visual, auditory; auditory, kinesthetic) can balance between two or three different modalities and be able to vary them freely. Young adults both in the learning environment and at work are flexible since they have to adapt to the conditions of activity that are imposed from the outside. It means that in the learning process the students can be joined to one of the three basic groups of visual, auditory and kinesthetic modality. And the more dominant modalities the students have, the more independent their choice is. Participating in various foreign language learning activities IT students can balance their abilities in perceiving information. So, they have to be flexible not only in the learning process but also in the IT professional environment.

The recommendations are represented in Table 3.

Table 3

Recommendations for organising differentiated ESP instruction of IT students with different sensory modalities

\begin{tabular}{|l|l|l|l|}
\hline $\begin{array}{c}\text { Modality } \\
\text { dominance } \\
\text { in IT } \\
\text { students }\end{array}$ & $\begin{array}{c}\text { Leading } \\
\text { language } \\
\text { skills }\end{array}$ & Specifics & \multicolumn{1}{c|}{$\begin{array}{c}\text { Recommendations for organising differentiated } \\
\text { instruction }\end{array}$} \\
\hline $\begin{array}{l}\text { Visual } \\
\text { modality } \\
\text { students }\end{array}$ & $\begin{array}{l}\text { reading, } \\
\text { writing }\end{array}$ & $\begin{array}{l}\text { image } \\
\text { presentation }\end{array}$ & $\begin{array}{l}\text { Use tables, charts, graphics, diagrams, mind maps. } \\
\text { When organising dialogues and polylogues give time for } \\
\text { preparation; follow the scheme: alone>pair>small group; } \\
\text { prepare algorithms. } \\
\text { When organising monologues prepare handouts, notes with a } \\
\text { plan, key phrases. } \\
\text { When organising listening activities suggest using subtitles, } \\
\text { varying the tempo, gradual increase in the length of the text. }\end{array}$ \\
\hline $\begin{array}{l}\text { Auditory } \\
\text { modality } \\
\text { students }\end{array}$ & $\begin{array}{l}\text { speaking, } \\
\text { listening }\end{array}$ & $\begin{array}{l}\text { verbal } \\
\text { presentation }\end{array}$ & $\begin{array}{l}\text { Use role plays, audio and video texts, brainstorming, group } \\
\text { work. } \\
\text { When organising reading activities suggest audio scripts. } \\
\text { For organising writing activities suggest writing summaries, } \\
\text { essays, reports based on reading and listening material. }\end{array}$ \\
\hline $\begin{array}{l}\text { Kinesthetic } \\
\text { modality } \\
\text { students }\end{array}$ & speaking & $\begin{array}{l}\text { physical } \\
\text { and hands- } \\
\text { on } \\
\text { presentation }\end{array}$ & $\begin{array}{l}\text { Use role plays, cards, work on a computer. } \\
\text { For organising reading, listening and writing activities } \\
\text { suggest surveys, projects. }\end{array}$ \\
\hline $\begin{array}{l}\text { Mixed } \\
\text { modality } \\
\text { students }\end{array}$ & $\begin{array}{l}\text { reading, } \\
\text { writing, } \\
\text { speaking, } \\
\text { listening }\end{array}$ & $\begin{array}{l}\text { combined } \\
\text { presentation }\end{array}$ & $\begin{array}{l}\text { Combine individual and group work, discussions and writing } \\
\text { reports, listening and reading activities. }\end{array}$ \\
\hline
\end{tabular}

The third issue is linked with analysing the results of defining the students' dominant way of processing information.

Bondar investigated learning styles of students of technical specialities (223 participators) according to D. Kolb's Learning-Style Inventory (Bondar, 2011, pp. 67, 76-80). She has found that technical students with concrete experience, reflective observation, abstract conceptualisation and active experimentation can be divided into two groups such as globalist and analytic students (Bondar, 2011, p. 80). The characteristics of these two groups are similar to those given by other scientists. According to the researchers synthetic/holistic/global students "use pieces to build new wholes (Dörnyei, 2005, p. 148), "are socially interactive, avoid analysis of grammatical minutiae, guess from the context, freely give synonyms and paraphrase, avoid analysis of words and sentences" (Oxford, 2003, pp. 6-7), whereas analytic students disassemble wholes into parts to understand their componential structure (Dörnyei, 2005, p. 148), concentrate on grammatical details, avoid synonyms and paraphrasing; analyse sentences, avoid more free- 
flowing communicative activities (Oxford, 2003, pp. 6-7). The investigation of Bondar (2011) has shown that analytic students (88\%) are more than globalist students (12\%) (p. 80). In our research, we define three groups of students. Most students have the synthetic way of processing information and mixed syntheticanalytic ways of processing information. It is in line with the statement of Oxford about learning styles operating on a continuum or multiple, intersecting continua (Oxford, 2003, p. 3). Such difference in results may depend on the tests themselves and the way of interpreting results.

The fourth issue covers the relation between verbal and nonverbal intelligence, theoretical and practical thinking, and mathematical and spatial intelligence.

Taking into account verbal and nonverbal intelligence in the learning process plays an important role in mastering ESP. Since, on the one hand, nonverbal intelligence enables IT students to analyse, to generalise, to use abstract and combinatorial thinking, to solve complex tasks connected with theoretical aspects of mathematics and physics, computer science and cyber security problems, on the other hand, verbal intelligence enables IT students to express complex concepts related to IT field in written and oral form. So, a foreign language is an instrument through which IT students learn to communicate on professional topics. Therefore, nonverbal intelligence and verbal intelligence are interconnected and interdependent. The testing results have shown that nonverbal intelligence is higher than verbal one. Nevertheless, verbal intelligence is not less than $50 \%$ and is developed on the sufficient level.

According to researches, the engineers who have developed nonverbal (the ability to spatial representations) and verbal (the ability to use verbal information) intelligence are successful in their work (Tutushkina, 2001, p. 40). Studying the intelligence of programmers, Orel (2007) writes about the obvious high level of verbal operations, paying attention to transcoding information from one language to another (p. 9).

It is important to mention that among the disciplines necessary for the future IT specialist is programming, the mastery of which is based on the knowledge of certain vocabulary, syntax and semantics of the programming language. Thus, it positively influences the development of verbal intelligence. The experience shows that mastering "artificial" languages such as $\mathrm{CH}, \mathrm{C}++$, etc. and "alive" languages, such as English, allows the future IT specialists to be multifunctional and rational in their actions, quickly switch from one activity to another in their professional environment. In addition, university entrants who have chosen the IT specialty as a future profession have to support basically a relative balance in the development of verbal and nonverbal type of intelligence. Consequently, the development of verbal and nonverbal intelligence will contribute to the rapid extracting and processing of information, structuring of ideas; easy paraphrasing; logical construction of both written and oral texts; increased ability to analyse, synthesise, generalise; creativity in solving professional problems through English communication; productive actualisation of knowledge in the process of mastering ESP. In contrast, undeveloped verbal and nonverbal intelligence leads to stereotyping and reproductive actions of students in solving communication tasks.

The misbalance between mathematical and spatial intelligence may be explained by the specifics of speciality that mostly needs mathematical knowledge. The relative balance between theoretical and practical thinking level of the third and fourth year IT students allows them to use a foreign language to substantiate, explain, assess, classify, inform the theoretical ideas of their innovations, and practically release them in the IT field.

\section{Conclusions}

The specifics of IT professional field when viewed from the cognitive perspective demand from specialists the fast perception and processing of specific textual, symbolic, and graphical information. That is why taking into account the sensory modality, the way of information processing, verbal and nonverbal intelligence that belong to cognitive aspect of language learning style is important for optimising ESP teaching to IT specialists in differentiated instruction. Further investigation of the motivation aspect of language learning style can also serve that purpose.

\section{References:}

Barbe, W.B. \& Milone, M.N. (1981). What we know about modality strengths. Educational Leadership, 38, 378-380. Retrieved October 19, 2018 from: http://www.ascd.org/ASCD/pdf/journals/ed_lead/el_198102_barbe.pdf

Barbe, W.B., Swassing, R.H. \& Milone, M.N. (1979). Teaching through modality strengths: concepts and practices. Columbus: Zaner-Bloser.

Barbe, W.B., Swassing, R.H., \& Milone, M.N. (1981). Teaching to modality strengths: Don't give up yet! Academic Therapy, 16, 261-266.

Barbe, W.B., \& Milone, M.N. (1982). Modality Characteristics of Gifted Children. G/C/T, 5(1), 2-5. https://doi:10.1177/107621758200500102

Bishop-Clark, C. (1995). Cognitive style, personality, and computer programming. Computers in Human Behavior, 11(2), 241-260. https://doi.org/10.1016/0747-5632(94)00034-f 
Bondar, L. V. (2011). Metody`ka navchannya franczuz`kogo profesijno spryamovanogo monologichnogo movlennya studentiv texnichny`x special nostej z uraxuvannyam yix navchal ny`x sty 'iv [Methodology of teaching French professional oriented monologue to students of technical specialties taking into account their educational styles]. Unpublished candidate dissertation, Kyiv National Linguistic University, Kyiv, Ukraine.

Brooks, C.J., Anderson, A.J., Roach, N.W., McGraw, P.V., \& McKendrick, A.M. (2015). Age-related changes in auditory and visual interactions in temporal rate perception. Journal of Vision, 15(2). https://doi.org/10.1167/15.16.2

Cassidy, S. (2004). Learning Styles: An overview of theories, models, and measures. Educational Psychology, 24(4), 419-444. https://doi.org/10.1080/0144341042000228834

Derkach, T. (2018). Preferred Learning Styles of Students Majoring in Chemistry, Pharmacy, Technology and Design. Advanced Education, 9, 55-61. https://doi.org/10.20535/2410-8286.131078

Dörnyei, Z. (2005). The Psychology of the Language Learner Individual Differences in Second Language Acquisition. Lawrence Erlbaum Associates, Publishers Mahwah, New Jersey, London.

Dreyer, C. \& Van der Walt, J.L. (1996). Learning and teaching styles: Empowering diverse learners in tertiary classrooms. Koers, 61(4), 469-482. https://doi.org/10.4102/koers.v61i4.611

Dunn, R. (1984). Learning style: State of the science. Theory Into Practice, 23(1), 10-19. https://doi.org/10.1080/00405848409543084

English for Specific Purposes (ESP). National Curriculum for Universities. (2005). Kyiv, British Council, Ukraine.

Grasha, A.F. (1984). Learning styles: the journey from Greenwich Observatory (1796) to the college classroom (1984). Improving College and University Teaching, 32(1), 46-53. https://doi.org/10.1080/00193089.1984.10533841

Grossmann, D. (2011). A study of cognitive styles and strategy use by successful and unsuccessful adult learners in Switzerland. Master of Arts dissertation, the School of Humanities of the University of Birmingham.

Guild, P.B. (2001). Diversity, Learning Style and Culture. New Horizons for Learning. Retrieved October 19, 2018 from: http://archive.education.jhu.edu/PD/newhorizons/strategies/topics/Learning\%20Styles/diversity.html

Kondrashihina, O.A. (2009). Differencial'naja psihologija [Differential Psychology]. Kiev, Ukraine: Centr uchebnoj literatury.

Leaver, B.L. (2000). Metodika individualizirovannogo obuchenija inostrannomu jazyku s uchetom vlijanija kognitivnyh stilej na process ego usvoenija [Methods of individualised learning a foreign language with taking into account the influence of cognitive styles on the process of its mastering]. Unpublished candidate dissertation, A. S. Pushkin State Institute of Russian Language, Moscow, Russia.

Mahadevan, L., Simon, J.C., Meservy, O.T. (2011). Effects of Developer Cognitive Style and Motivations on Information Security Policy Compliance. AMCIS 2011 Proceedings of the Seventeenth Americas Conference on Information Systems, Detroit, Michigan. August 4th-7th 2011, 1-8. Retrieved October 19, 2018 from: https://pdfs.semanticscholar.org/27e0/fc8a2edd2871f9b2fc869e682e88e40c3a35.pdf

Margaryan, A., Bianco, M., \& Littlejohn, A. (2015). Instructional quality of Massive Open Online Courses (MOOCs). Computers \& Education, 80, 77-83. https://doi.org/10.1016/j.compedu.2014.08.005

Myers, I.B., McCaulley M.H. (1985). Manual: a guide to the development and use of the Myers-Briggs Type Indicator. Palo Alto, CA: Consulting Psychologists Press.

Orel, E.A. (2007). Diagnostika osobennostej myslitel'noj dejatel'nosti specialistov v oblasti informacionnyh tehnologij (programmistov) [Diagnostics of the mental activity features of specialists in the field of information technology (programmers)]. Extended abstract of candidate's thesis, M.V. Lomonosov Moscow State University named, Moscow, Russia.

Oxford, R.L. (2003). Language learning styles and strategies: an overview. Learning Styles \& Strategies, 1-25. Oxford, GALA. Retrieved October 19, 2018 from: http://web.ntpu.edu.tw/ language/workshop/read2.pdf

Oxford, R.L. (1992). Who Are Our Students? A Synthesis of Foreign and Second Language Research on Individual Differences with Implications for Instructional Practice. TESL Canada Journal, 9(2), 30-49. https://doi.org/10.18806/tesl.v9i2.602

Rebecca Oxford's Style Analysis Survey (SAS). Learning Styles Workshop of M. Walline (1996). Talpiot College. May. Retrieved October 19, 2018 from http://gordonintensive2012-13.yolasite.com/resources/Oxford\%20Style\%20Analysis.pdf

Riding, R., Rayner, S. (1988). Cognitive styles and Learning Strategies. London. David Fulton Publishers. https://doi.org/10.4324/9781315068015

Santangelo, T., \& Tomlinson, C. A. (2012). Teacher Educators' Perceptions and Use of Differentiated Instruction Practices: An Exploratory Investigation. Action in Teacher Education, 34(4), 309-327. doi:10.1080/01626620.2012.717032

Suprayogi, M. N., Valcke, M., \& Godwin, R. (2017). Teachers and their implementation of differentiated instruction in the classroom. Teaching and Teacher Education, 67, 291-301. https://doi.org/10.1016/j.tate.2017.06.020

Tight, D.G. (2007). The Role of Perceptual Learning Style Preferences and Instructional Method in the Acquisition of L2 Spanish Vocabulary. Doctor of philosophy dissertation, the University of Minnesota.

Tarver, S. G., \& Dawson, M. M. (1978). Modality Preference and the Teaching of Reading: A Review. Journal of Learning Disabilities, 11(1), 17-29. https://doi.org/10.1177/002221947801100103

Tutushkina, M.K., Artem'eva, V.A., Volkov, S.A., Godlinik, O.B., Gulina, M.A. (2001). Prakticheskaja psihologija [Practical psychology]. 4-e izd., pererab., dop. SPb. Izd-vo "Didaktika Pljus”. 